\title{
The Impact of Financing to Small Businesses and the Challenges Facing This Sector
}

\author{
Bader AL Qaied ${ }^{1}$, Nesreen Ennab ${ }^{2} \&$ Rasha Neamat ${ }^{3}$ \\ ${ }^{1}$ Department of Business Administration, Ajloun National University, Jordan \\ ${ }^{2}$ Microfund for Womane, Jordan \\ ${ }^{3}$ Jordan Commercial Bank, Jordan \\ Correspondence: Bader AL Qaied, Department of Business Administration, Ajloun National University, Jordan. \\ E-mail: bader1357@outlook.com
}

Received: October 1, 2015

Accepted: October 26, 2015

Online Published: November 25, 2015

doi: 10.5539/ibr.v8n12p125

URL: http://dx.doi.org/10.5539/ibr.v8n12p125

\begin{abstract}
The purpose of this study was to identify the impact of the funds on small projects and the obstacles facing this section. The section of projects funded was selected by a non-profit Jordanian company Ajloun women branch (the first in Jordan to fund small and micro enterprises).
\end{abstract}

Keywords: small projects, micro-finance, small business administration, small capacity and the type of project, quality products for small business, small business challenges

\section{Introduction}

\subsection{Introduce the Problem}

Despite the development efforts that are made by many developing countries, but it still suffers from some of the various economic problems and most important: - lower average per capita income and standard of living, and increasing unemployment rates and increased indebtedness. With the complexity and exacerbate of these problems the sense of the need for self-reliance is Heightened, and the mobilization of local resources and to make room to the private sector has a greater role in development processes (Almberek \& Al-Shammari, 2006).

Here comes the importance of small enterprises and the role it can play as it features by spread, they constitute almost $90 \%$ of the establishments in the world and employs from $50 \%-60 \%$ of the world's labor force, and thus works to increase employment opportunities and works to resolve the problem of unemployment and to increase exports and works on the treatment of balance of payments deficit. Small businesses also contribute about $46 \%$ of world GDP, and represent 65\% of the GDP in Europe compared with 45\% of American States, while in Japan, $81 \%$ of the jobs are small and medium enterprises. (Latha \& Murthy, 2009) it can be argued that small businesses considered as a backbone of the national economy (Afaneh \& Abu Eid, 2004). Small projects also help to increase the national output and economic growth of the countries. Most of the people in developing countries rely heavily on personal employment or small businesses as a source of income (Prasad \& Tata, 2009), for these reasons, the issue of small enterprises enjoy great importance to the economic decision-makers in developed and developing countries, including the Hashemite Kingdom of Jordan, both because of its central role in sustainable economic and social development.

\subsection{Research Importance}

Small enterprises have become the focus and attention of most of the governments of developing countries, especially in Jordan because of the large role they play in increasing production and employment as well as large and active contribution to the increase rates of economic growth and increase national income and support the GNP of many countries, especially Jordan due to limited resources and work opportunities, The importance of the research shows in identifying the impact of financing small shopkeepers in Ajloun and the most important obstacles facing small enterprises from the viewpoint of entrepreneurs in Ajloun.

\subsection{Find Objectives}

On the grounds that small businesses forms the backbone of the economy in all countries of the world, without exception, the aim of the research is an attempt to provide some of the solutions that may help in treatment of 
financing small enterprises problem especially in developing countries, especially Jordan with the identification of the most important reasons that face individuals (Small entrepreneurs) in the financing of their small projects. And stand at the impact of the funds on the profitability and sustainability of these projects in light of the large and fast variables.

\subsection{Problem of the Study}

The problem with research is to identify the point of view of small entrepreneurs with regard to the problems of (financial and administrative) to try to find some solutions that can help to increase support for small enterprises and provide the necessary funding and work to develop and increase its spread because of its core importance in the economic development and in solving the problem of unemployment.

\subsection{Main Study Hypotheses}

Through study problem the study is based on the following key assumptions:

1-Rising numbers of beneficiaries of small loans and sound investment of loans is of the most important effects of small loans.

2-Small loans provided jobs opportunities even if they are modest proportions.

3-Administrative procedures and the lack of advisory services are of the main obstacles to finance small enterprises.

4-Ease of guarantees and the speed of service and competitive interest between competitors.

5-Lack of a permanent marketing channels provided by the company to customers.

\subsection{Affiliated Hypotheses}

1-High installments funds and the short duration of repayment effects on client and projects thus leads to stumble the loan.

2-low-grant funding for the required amount affects to the non-continuation of the project and increase the indebtedness without the benefit.

\subsection{Study Questions}

1-What are the installments that fit the client and the project and comfortable repayment periods?

2-How to get to a sound study to reach the financing needs of the actual client?

3-How can customers products be discharged through marketing channels?

\subsection{Search Terms}

Enterprise: a plan or proposal for the production of a new product or business.

There is no universal definition of a small business and the scientific and practical view varied, because the small-term project "Small Business" holds between its aspects many questions, including:

1) Type of small business;

2) Minimum and maximum employment;

3) Minimum and maximum investment;

4) Distribution of business products energy;

5) Small business products quality;

6) Management and Administration form in these projects;

7) Technological level used in small-scale project;

8) The small business form from the legal aspect;

9) Project realism image-workshop-factory-house. All of these standards from our point of view contribute to defining the concept of small business, and we can say that the concept of small business is a project that does not depend on technological density in general, handcraft is the foundation of the small business-employment number no more than five members-its maximum capital of ten thousand to fifteen thousand pounds there is no separation between ownership and management (owner of the business, which the business is run by) products are characterized by simplicity-its goal is to cover local environment with its needs. Finance: is the business source of financing, whether to borrow from banks or any specialized funding sources or a personal finance from the same person. 


\section{Literatures Review}

1) Asameerat, Youself study (2009), entitled "The financial and administrative problems facing small business in the North territory," study focused on the identification of financial and administrative problems faced by small business owners in the South territory through a field study on a sample of 260 businesses, The researcher reached a set of results, most important that the lack of capital availability and the lack of guarantees problems came first in terms of their importance, and the lack of administrative, financial and marketing expertise was one of the main reasons for the failure of some of these businesses, the researcher recommended the need to develop effective and well-studied programs and work on the training and qualification of owners these projects.

2) While a researcher's study Alnosoor, Iyad, (2008), entitled "Measuring government funding directed efficiently toward small business development in Jordan", which aimed to estimate the production function for small business funded by government institutions in Jordan through the application of standard economic models to test hypotheses of the study (Cobb Douglas production function and Farrell efficiency standard) The study found several results, most important of which was that some small business funded by these institutions was intensive in work item and there are other projects are capital-intensive, and researcher recommended in the study the need to work on the establishment of a supreme body for the development of small businesses in Jordan and working on the integration of government financing institutions in one institution.

3) The study of Dwabh, Ashraf (2006) entitled "The problem of financing small and medium enterprises in the Arab countries," which aimed to recognize the importance and the reality of small businesses in the Arab countries and the problems of financing and methods of treatment by relying on Islamic funding methods. Which was of the recommendations reached by the study, the need to study the application of Islamic financing methods in the financing of small projects, and work on activating the role of the Arab Union for small businesses and to provide the regulatory environment for that, with achieving the partnership of efforts between the Arab states. There are many Arab studies conducted study and research in the ways and methods of Islamic for finance small businesses as one of the methods that may help alleviate the small business financing problems such as the study of Omar, Mohammed, (2004) "Islamic financing techniques based on commercial credit to small businesses" and Shehata, Hussein study, (2004), "A proposed model for financing small businesses with participation system ended with ownership between the thought and the application".

4) Dickinson, Paul (2000) entitled "The shift in economies of Eastern Europe: assessment of the role and contribution of small businesses in the private sector" through which to examine the role and the contribution of small businesses in the private sector in achieving economic growth in Poland by referring to their importance in restructuring programs and the need to consolidate its role in economic growth through appropriate legislation and appropriate framework for its work, the researcher recommended the need to provide adequate managerial skills and the tendency to take risks with the appropriate economic climate in Poland compared with the Eastern European countries, however, the researcher confirms the need for the government to encourage small industrial businesses.

5) Junjie, Jining, and Ctherine (2008), Study, entitled "The empirical evidence for the financing of small businesses in China". The researchers worked to provide evidence of the amount of connection with the financing of small and medium businesses with reference to the funding problems facing these projects in order to develop its business, and in the end of the research, the researchers found that the financing needs and options for these projects vary depending on the size and stage the business cycle go through on the grounds that funding at the beginning of the project is done through private funds, and in the advanced stages of the project, the need for loans increases, The study also found that the biggest part of small businesses rely on bank loans.

6) Singh, Gang, and Deshmuck (2010), study, entitled "Competitiveness small and medium businesses in the Globalization economy". The study aimed to analyze the challenges facing small and medium-sized businesses in both India and China after the globalization by studying the development of these projects, governments policies and strategies for the development of competitiveness. The study found that both India and China has developed a number of incentive programs in this regard, but the study recommended the need to work on the development of management skills and their relationship to cut costs while working to improve quality, which is strongly linked to improving competitiveness.

\section{Small Businesses in Jordan}

Small and medium-sized businesses in Jordan are characterized by that they form more than $90 \%$ of the total working institutions in various economic sectors, where they accommodate about $60 \%$ of the labor force, and contributes nearly $50 \%$ of GDP. Which means the need to give these institutions great importance in Jordan through development and overcome the obstacles that limit their growth to be a key driver of the forces of the 
national economy in various fields. The estimated total accumulated funding size that these institutions provided nearly half a billion Jordanian dinars, contributed to the financing and the creation and development of (134) thousand enterprises, and provided about eighty thousand permanent jobs since the end of the last century. Jordan began to follow economic reform and market liberalization policies, the first achievements of this approach was the signing of a free trade agreement with the EU in 1997, followed by the accession to the World Trade Organization in April of 2000, with the aim of improving the lives of Jordanian citizens level by achieving an annual economic growth rate of 6-7\% and the reduction of unemployment by creating job opportunities for Jordanian citizens, and the opening of the Jordanian market to industrial, commercial and service of various investments, and to promote competition in the Jordanian market, which leads to the reduction of high prices and to the diversification of products in the local market with prices that fit the Jordanian consumer.

The year 1959 is the beginning of funding small businesses in Jordan through the Agricultural Credit Corporation through the provision of loans to farmers, and in 1965 this sector was strengthened through the establishment of Industrial Development Bank (Al-Nabulsi \& Shalabi, 2009).

Jordan began to encourage small businesses in the early seventies, through the five-year economic development plan (1976-1980), which promoted the social and economic development and the trend towards small projects that produce a substitute for imported goods and products. In 1984 the Jordanian company to secure loans were established with a capital of 10 million dinars, while in 1986 the Federation of charities was established, as the plan focused on the promotion of agro-industries and the development of handicrafts, and in 1989 an economic program were developed to achieve economic and monetary stability, which included an economic and social plan to provide employment opportunities for Jordanians in the field of small businesses. (Al-Nabulsi \& Shalabi, 2009), and in 1998 in the fight against poverty and unemployment, the government through the Ministry of Planning and International Cooperation launched a social security package program in order to improve living conditions for the poor and increase economic and social productivity, and in 2002 for the same goals the government has also launched a another program to support the previous program, and in 2003 the two programs was integrated within a single package is the "economic and social productivity programs", which include the development of small businesses, where the equivalent of 17.14 million dinars were spent until 2005 on the development of small businesses (Ministry of Planning and International Cooperation. We can call the nineties period the revolution of institutions of funding small businesses where many businesses were established during this period Women's Lending Fund and civil fund Company to finance small nineties and Tamweelcom and Middle East company of funding small businesses (and in 2005 the National Bank to finance small businesses joined these institutions (Nabulsi \& Shalabi, 2009) and in 27March, 2006, the Bank's work was inaugurated as the first Arab bank financing small and micro businesses (Middle East Online Site).

As a key tributary to increase the production capacity on one hand, and to contribute to addressing the problems of poverty and unemployment on the other hand, a lot of countries, including Jordan's paid growing attention to this type of businesses. Small businesses achieves integration and homogenization of public structures for industrial development because they use a simple production methods and achieve a quick return, as these businesses contribute to attracting small savings and characterized by high capital turnover rate of making it a nucleus for large businesses (and there are several institutions dealing with the financing of projects small, directly and indirectly, such as Women lending Fund, which was founded in 1999 as a private profit Jordanian foundation, in order to support production capacity for small businesses, it is also working to empower women and strengthen its position as a productive individual in the community where the Fund provided 114 thousand loans for about 40 thousand people, $99 \%$ of them women in 2005.

\subsection{About the Women's Fund}

Fund's message: To provide financial and non-financial services sustainable for women in small businesses from low-income families to improve their standard of living and their families and empower women economically and socially.

Vision: We in the Women's Fund look forward to a more just and equal society where women can break the cycle of poverty and achieve prosperity and well-being in their lives for integrated life, Women's Fund experimentally under the name of "lending program by guarantee of the Group" in Amman, it was created by Save the Children in 1994 in order to enable the entrepreneurs from women to become income-generating and decision makers in their homes and communities. This program was the first program to finance small businesses in Jordan, and based on the application of best practices. Two years later, program became a local NGO called "Jordanian Women's Development Association" to achieve two objectives, first is to test the feasibility of group lending in Jordan, and the second to enable poor women to obtain loans mechanisms. And success exceeded all 
expectations. In 1999, the program became fully independent and became a non-profit limited liability company registered in the Ministry of Industry and Trade as the "Women's Fund".

Her Majesty Queen Rania and MFW Chairman Ghaith Sukhtian mark MFW's 10th anniversary in 1994, and by 2002, the Fund was able to achieve full financial sustainability and reached 25,000 of the loans outstanding in 2006. The fund won the regional Sanabel Award for the best investment in microfinance in 2006 Since its launch, the "Fund" played an important role in the financing of small businesses in Jordan, which touched the lives of tens of thousands of families. Today, the Women's Fund is still at the forefront of institutions that enable women and their families from achieving that. The first microfinance program in Jordan more than 106 thousand beneficiaries-97\% women, repayment rate of up to $99 \%-57$ branch in all governorates of the Kingdom of Jordan.

A team of 568 male and female employees of more than 684 thousand financing worth 262 million dinars since inception.

\subsection{Obstacles Facing Small Businesses}

Many small businesses face several obstacles stands as a stone block in achieving economic and social objectives, and the nature of these obstacles vary depending on the nature of the project and activity practiced

Many studies indicate that the owners of new businesses suffer from inadequate funding and bad product and ineffective marketing (O`Dwyer \& Ryan, 2000) and the local consumer preference of similar foreign products motivated by tradition, and the lack of adequate incentives for local products to boost their competitiveness compared to foreign product, and follow dumping policy by some foreign institutions significantly weaken local product competitiveness.

We must not lose sight of inflation, which is a major cause of the high prices of raw materials and wages of workers and thus higher operating costs for this type of projects leading to higher prices for its products and that means not being able to cope with intense competition from large enterprises (Kandah, 2009) as well as government actions and high tax rates on these businesses are of the main obstacles to the development of this sector.

\section{The Results of the Field Study}

100 questionnaires were distributed to an intended sample of small businesses in Ajloun and who have already progress to obtain a loan from a branch by the woman fund in Ajloun. 80 questionnaires were obtained, 80 of which were valid and 20 were invalid and were excluded for the purposes of analysis, after the data were obtained and processed statistically, were obtained the following results for the characteristics of the sample:

Table 1 . The characteristics of the study sample

\begin{tabular}{|c|c|c|c|c|c|c|c|c|c|c|c|}
\hline \multicolumn{2}{|c|}{ Sex } & \multicolumn{2}{|c|}{ Age group } & \multicolumn{2}{|c|}{ Education Level } & \multicolumn{2}{|c|}{$\begin{array}{c}\text { The overall shape of } \\
\text { the project }\end{array}$} & \multicolumn{2}{|c|}{$\begin{array}{c}\text { Distribution of projects } \\
\text { between different } \\
\text { sectors } \\
\end{array}$} & \multicolumn{2}{|c|}{$\begin{array}{c}\text { The acquisition of } \\
\text { the project site } \\
\text { method }\end{array}$} \\
\hline \multirow[t]{2}{*}{ Male } & \multirow[t]{2}{*}{$30 \%$} & $20-25$ & $25 \%$ & $\begin{array}{c}\text { Less than a } \\
\text { baccalaureate }\end{array}$ & $25 \%$ & $\begin{array}{l}\text { Individual, } \\
\text { whether a } \\
\text { home or } \\
\text { independent }\end{array}$ & $50 \%$ & Commercial & $35 \%$ & Guarantee & $3 \%$ \\
\hline & & $\begin{array}{l}31-35 \\
36-40\end{array}$ & $\begin{array}{l}30 \% \\
10 \%\end{array}$ & $\begin{array}{c}\text { Diploma } \\
\text { Bachelors }\end{array}$ & $\begin{array}{l}15 \% \\
10 \%\end{array}$ & Solidarity & $10 \%$ & Craftsman & $2 \%$ & Rental & $35 \%$ \\
\hline Female & $50 \%$ & $\begin{array}{l}41 \text { and } \\
\text { above }\end{array}$ & $9 \%$ & $\begin{array}{c}\text { Master } \\
\text { Doctorate }\end{array}$ & $\begin{array}{c}0 \\
0\end{array}$ & $\begin{array}{l}\text { Public, service } \\
\quad \text { or taxi }\end{array}$ & $20 \%$ & Services & $15 \%$ & $\begin{array}{l}\text { inside the } \\
\text { house }\end{array}$ & $30 \%$ \\
\hline
\end{tabular}

We note through the analysis above, that the higher the percentage of beneficiaries of the Fund is Women sector, it was $50 \%$. As for the age group was 30-31, followed by 36-40, educational level, the highest percentage for less a baccalaureate, the overall shape of the businesses and the vast majority of the projects was between in home and independent the highest sectors are commercial where it formed (35\%) and the highest rate of businesses acquisition methods is rental (35\%). 
Table 2. The impact of financing to small businesses

\begin{tabular}{cl}
\hline & \multicolumn{1}{c}{ The impact of financing to small businesses } \\
\hline $68 \%$ & Have you took advantage of the funding? \\
$26 \%$ & Did small businesses provided employment opportunities to the local community? \\
$5 \%$ & Was there any input in social responsibility (exploitation of the remnants of the project, \\
$6 \%$ & Use of non-harmful substances to the environment, making awareness-raising activities through your project)? \\
$\mathbf{6 \%}$ & Did you introduced new and competitive products in Ajloun market? \\
$2 \%$ & Have new technology introduced or new machines and machinery were used? 2\% \\
\hline
\end{tabular}

We note through the above analysis, the first hypothesis making use of funding and proper investment where the rate formed $67 \%$ this rate is high and excellent and this shows the success of the small financing in the industry of small businesses and its influence, also there is a confirm and agree with the second hypothesis which is the capacity of small businesses to provide employment opportunities to the local community.

Social responsibility formed 5\%, which indicates a lack of awareness and knowledge of small businesses responsibility towards the environment and the local community.

The new products small businesses also formed $6 \%$, which demonstrates the imitation of customer to each other in the business. Which gives customers the ability to research and innovation and the ability of sustainability and continue the businesses through the introduction of new and competitive products.

Table 3. The challenges facing small businesses

\begin{tabular}{|c|c|c|c|c|c|c|c|c|}
\hline Question & $\begin{array}{l}\text { Strongly } \\
\text { Agree }\end{array}$ & Agree & Neutral & $\begin{array}{l}\text { Do not } \\
\text { Agree }\end{array}$ & $\begin{array}{c}\text { Strongly } \\
\text { Donot Agree }\end{array}$ & $\begin{array}{l}\text { Std. } \\
\text { Dev. }\end{array}$ & Mean & Sig. \\
\hline $\begin{array}{l}\text { Microfinance institutions work to provide full } \\
\text { funding required for the project }\end{array}$ & $22 \%$ & $22 \%$ & $24 \%$ & $28 \%$ & $4 \%$ & 1.171 & 3.227 & .000 \\
\hline $\begin{array}{l}\text { microfinance institutions stresses in the request } \\
\text { of guarantees. }\end{array}$ & $26 \%$ & $58 \%$ & $14 \%$ & $2 \%$ & 0 & 0.667 & 4.111 & .000 \\
\hline $\begin{array}{l}\text { The benefits of microfinance loans are } \\
\text { considered too high. }\end{array}$ & $30 \%$ & $46 \%$ & $20 \%$ & $4 \%$ & 0 & 0.815 & 3.974 & .000 \\
\hline $\begin{array}{l}\text { loan payment of small business period is is not } \\
\text { sufficient. }\end{array}$ & $14 \%$ & $46 \%$ & $28 \%$ & $8 \%$ & $4 \%$ & 0.849 & 4.026 & .000 \\
\hline $\begin{array}{l}\text { requested loan ratio is considered low } \\
\text { compared to the size of the requested loan } \\
\text { (margin ratio) }\end{array}$ & $20 \%$ & $50 \%$ & $20 \%$ & $8 \%$ & $2 \%$ & 0.825 & 3.412 & .000 \\
\hline Lack of sufficient grace period & $28 \%$ & $52 \%$ & $12 \%$ & $8 \%$ & 0 & 1.096 & 2.780 & .000 \\
\hline $\begin{array}{l}\text { Facing difficulties and problems to pay the due } \\
\text { installments in time }\end{array}$ & $12 \%$ & $38 \%$ & $30 \%$ & $16 \%$ & $4 \%$ & 1.014 & 3.326 & .000 \\
\hline $\begin{array}{l}\text { The requested loan ratio is considered low } \\
\text { compared to the desired size of the loan margin } \\
\text { ratio }\end{array}$ & $12 \%$ & $30 \%$ & $16 \%$ & $34 \%$ & $8 \%$ & 0.877 & 3.512 & .000 \\
\hline The loan amount is not enough & $12 \%$ & $48 \%$ & $22 \%$ & $14 \%$ & $4 \%$ & 0.922 & 3.521 & .000 \\
\hline $\begin{array}{l}\text { The microfinance institutions to provide } \\
\text { advisory services to borrowers. }\end{array}$ & $16 \%$ & $32 \%$ & $24 \%$ & $20 \%$ & $8 \%$ & 0.954 & 3.643 & .000 \\
\hline \multirow[t]{2}{*}{$\begin{array}{l}\text { The nature of the grants does not agree with } \\
\text { Islamic profit system }\end{array}$} & $23 \%$ & $24 \%$ & $20 \%$ & $30 \%$ & $3 \%$ & 1.150 & 3.120 & .000 \\
\hline & $6 \%$ & $44 \%$ & $44 \%$ & $2 \%$ & $4 \%$ & 1.156 & 3.162 & .000 \\
\hline The overall average & & & & & & 0.958 & 3.484 & \\
\hline
\end{tabular}

Through the analysis above we note hypothesis compatibility, which says easily make the guarantees and the speed of the application, as well as low interest and competition between competitors companies where it had a ratio of $(46 \%)$.

We conclude that small businesses funding in Jordan suffers from many obstacles, the most important is lack of sufficient funding with high interest lending rates, as well as the microfinance institutions militancy request guarantees and with the limited guarantees by the loan applicants, and the absence of the active role of the government and routine administrative procedures are also considered of funding obstacles. 


\section{Conclusions}

1) Small businesses faces the problem of militancy in the request for guarantees by donors parties and approval by $84 \%$-Question (2), and that the benefits of microfinance are high and with a rate of approval reached 76\%-Question (3).

2) $76 \%$ of the sample of the study stressed that the repayment period is not considered enough question-(4), and the loan amount is not considered sufficient to finance the project needs, with approval rate reached 70\%-Question (5).

3) The approval of the loan application requires long and routine procedures-Question (6) and (7).

4) $60 \%$ of the study sample question (9) supported by the commercial banks by providing funding necessary for small businesses, but there is an absence of government's role in providing the required support to small businesses, question-(10).

5) $50 \%$ of the sample of the study suffers from the problem of the loan installments payment on time, and that $47 \%$ of the sample loan applications was rejected in advance.

6) $46 \%$ of the sample of the study stressed that the repayment period is not considered sufficient. Also, the loan amount is not considered sufficient to finance the project needs and with approval rate reached $48 \%$.

\section{Recommendation}

1) The need for the commercial banks and microfinance institutions to provide adequate support for small businesses in order to achieve economic development and work to resolve the problems of unemployment.

2) Microfinance institutions must work to ease the collateral required for the loan and to ensure to grant the loan only with the project guarantee itself without the need for other guarantees.

3) In order to expand the base of beneficiaries of the loans, it is necessary for the microfinance institutions to reduce interest rates, which is one of the most important funding constraints faced by the owners of these projects, and we can take advantage of the feature of increased number of borrowers in this situation and to achieve better profit.

4) The importance of the government to establish an institution to guarantee loans granted to finance small businesses, and work on the establishment of an investment fund to support small businesses specially in Jordan on the grounds that it is a developing country, as small businesses constitutes $90 \%$ of the total economic businesses.

5) Small businesses to do a proper study of the needs of the necessary financing for customers and that there is a flexible repayment duration.

\section{References}

Abboud, K. (2007). Investment and financing strategy in small business - A field study to small businesses in the city of Aleppo. Paper presented to the Fifth Scientific Conference, Philadelphia University, 4-5 / July / 2007, Amman, Jordan.

Abu, A., \& Ziad. (2009). The role of small businesses in the fight against poverty and unemployment in the Arab world. Thaqafa for Publishing and Distribution, United Arab Emirates, pp. 40-56.

Abu, M., \& Abdul, H. (2003). Faisal Islamic Bank experience in the financing of medium and small businesses. Work paper submitted to the sixth Muslim annual meeting: The role of Islamic banks and financial institutions in the financing of small and medium businesses, Amman: Arab Academy for Banking and Financial Sciences.

Afaneh, J., \& Abu, E, Q. (2004). Small Business Administration (pp. 1-15). Dar Yazouri Scientific Publishing and Distribution, Amman, Jordan.

Alatheem, \& Ahmed Al-Jazeera. (2007). Unemployment in the Arab world, Facts and Figures.

Alhawwat, \& Ali. (2007). The youth microenterprise and integration in the development and the labor market: the experience of Libya. A national seminar on small and medium businesses as an option to reduce unemployment and the future of young people in the Arab countries, Tunisia, 3 to 5 September 2007.

Alkhaseeb, \& Sabri. (2009). Small and medium businesses in Jordan, the reality and aspirations (3rd ed.). Amman room of Commerce, Studies and Training Administration, Electronic Magazine, Amman, Jordan.

Al-Khatib, \& Fred. (1994). Small businesses: developmental role and the impact of industrialization on policies. 
Labour magazine, No. 27, p. 24.

Al-Rai. (2008). A regional conference of banks of financing small and medium businesses looking to find an attractive environment to encourage it.

Alzerra, A., \& Rashdan, M. (2005). Assessment of operational and financial performance of the Jordanian firm of loans grants. Fourth Scientific Conference of the League of Philadelphia under the title: Entrepreneurship and Innovation-business strategies in facing the challenges of globalization 15-16/3/2005, Amman, Jordan.

Almahrouq, M., \& Moqabala, E. (2006). Small and medium businesses, its importance and constraints. The SME Center, Amman, Jordan.

Almberek, M., \& Al-Shammari, T. (2006). The establishment and management of small businesses (pp. 5-100). Council of Scientific Publications, Kuwait University, Kuwait.

Al-Nabulsi, S., \& Chalabi, A. F. (2009). Appropriate micro-finance systems to develop the local community. A worksheet submitted to the Second Regional Conference - innovation and initiatives in Arab cities, 27 to 29 April 2009, Amman, Jordan.

Al-Najjar, F. (1999). Small and business management, and new projects, business men, free professions and private investments guide for small and medium-sized businesses. University youth Foundation, Alexandria, pp. 9-10.

Amman room of Industry. (2002). The reality of Jordanian small and medium industries in the recent trends. A worksheet submitted to the seminar on the status and the problems of small and medium-sized businesses and ways of development, the Arab Organization for Administrative Development, Riyadh, October 2002.

Asameerat, B. (2009). Financial and administrative problems faced by small businesses in the North territory studies. Jordanian Science, 36(2), S396-414.

Dwabh, \& Ashraf. (2006). The problem of financing small and medium-sized businesses in the Arab countries. Journal of Management Research, Consulting, research and development center, Sadat Academy for Management Sciences, Fourth Issue, October.

EJAB. (2007). World Trade Consultant, legal mechanisms to strengthen the ability of the poor of licensing and doing business in Jordan.

El-Beltagy, \& Mohammed. (2005). Proposed formulas for financing small enterprises and the accounting processing of the sharing formula ending eith ownership. Twelfth annual conference of the Arab Academy for Banking and Financial Sciences under the title: The role of banks and financial and economic institutions in the promotion and financing of small and medium businesses, Jordan.

Farajat, I. (2009). The reality of small and medium enterprises in the Arab world. The Financial and Economic Blog, Internet, September 7, 2009.

Gabriel, \& Ahmad. (2002). The role of Islamic banks in the financing of small-scale industry with the application on Faisal Islamic Bank of Sudan. Paper presented to the Conference of the role of Islamic banking institutions in investment and development, University of Sharjah, Sharjah.

Jaradat, \& Suhad, (2004). The role of the Jordanian banking sector in financing small industrial businesses in Jordan (1982-2001). Unpublished Master Thesis, Al al-Bayt University, Mafraq.

Jawad, \& Abdul, H. (1994). The design and management of support services for small and medium enterprise workers. A seminar of executives in Commerce and Industry, the International Bureau of Commerce, Beirut, p. 132.

Kandah, A. (2009). Monetary and fiscal policies and their impact on retail lending and financing small and medium businesses. Jordan Banks Association, September 2009, Amman, Jordan.

Kengo, A. (2007). Investment and financing strategy in small businesses-field study for small businesses in Aleppo city. Fifth Scientific Conference, Philadelphia University, Amman, Jordan.

Omar, M. (2004). Islamic financing techniques based on commercial credit to small businesses. A research presented to a seminar of Islamic financing methods for small businesses, Saleh Kamel Center, Al-Azhar University, Egypt.

Shehata, H. (2004). A proposed model for financing small businesses with participation of ended sharing system with ownership between the thought and the application. Paper presented to a symposium of Islamic 
financing methods for small businesses, Saleh Kamel Center, Al-Azhar University, Egypt.

Tanash, A. (2003). A Worksheet submitted to the sixth annual Islamic meeting: The role of Islamic banks and financial institutions in the financing of small and medium enterprises. Amman: Arab Academy for Banking and Financial Sciences.

\section{Copyrights}

Copyright for this article is retained by the author(s), with first publication rights granted to the journal.

This is an open-access article distributed under the terms and conditions of the Creative Commons Attribution license (http://creativecommons.org/licenses/by/3.0/). 